\title{
HOW DO PENSIONS AFFECT EXPECTED AND ACTUAL RETIREMENT AGES
}

\author{
Alicia H. Munnell, Robert K. Triest, and Natalia A. Jivan* \\ CRR WP 2004-27 \\ Released: November 2004 \\ Draft Submitted: October 2004
}

\author{
Center for Retirement Research at Boston College \\ 550 Fulton Hall \\ 140 Commonwealth Ave. \\ Chestnut Hill, MA 02467 \\ Tel: 617-552-1762 Fax: 617-552-1750 \\ http://www.bc.edu/crr
}

\begin{abstract}
* Alicia H. Munnell is the Director of the Center for Retirement Research (CRR) and the Peter F. Drucker Professor of Management Sciences at Boston College's Carroll School of Management. Natalia A. Jivan is a graduate student at Boston College and a research associate at the Center. Robert K. Triest is Assistant Vice President and Economist at the Federal Reserve Bank of Boston. The research reported herein was performed pursuant to a grant from the U.S. Social Security Administration (SSA) to the Center for Retirement Research at Boston College (CRR). The opinions and conclusions are solely those of the authors and should not be construed as representing the opinions or policy of SSA or any agency of the Federal Government or the CRR.
\end{abstract}

(C) 2004, by Alicia Munnell, Natalia A. Jivan, and Robert K. Triest. All rights reserved. Short sections of text, not to exceed two paragraphs, may be quoted without explicit permission provided that full credit, including $($ ) notice, is given to the source. 


\title{
About the Center for Retirement Research
}

The Center for Retirement Research at Boston College, part of a consortium that includes a parallel centers at the University of Michigan and the National Bureau of Economic Research, was established in 1998 through a grant from the Social Security Administration. The goals of the Center are to promote research on retirement issues, to transmit new findings to the policy community and the public, to help train new scholars, and to broaden access to valuable data sources. Through these initiatives, the Center hopes to forge a strong link between the academic and policy communities around an issue of critical importance to the nation's future.

\author{
Center for Retirement Research at Boston College \\ 550 Fulton Hall \\ 140 Commonwealth Ave. \\ Chestnut Hill, MA 02467 \\ phone: 617-552-1762 fax: 617-552-1750 \\ e-mail: crr@bc.edu \\ http://www.bc.edu/crr
}

\section{Affiliated Institutions:}

American Enterprise Institute

The Brookings Institution

Center for Strategic and International Studies

Massachusetts Institute of Technology

Max Planck Institute for Demographic Research

Syracuse University

Urban Institute 


\begin{abstract}
This paper uses the first six waves of the Health and Retirement Study to investigate the impact of pensions on expected retirement age, on the probability of being retired in each wave given employment in the previous wave, and on the probability of retiring earlier than planned. Pension coverage per se and the type of pension are important in each case. Pension wealth reduces the expected retirement age by 0.6 year, and the incentives in defined benefit plans lower the expected age by another 1.1 years. Pension wealth increases the probability of retiring in a given wave, and pension accruals reduce the probability. Other characteristics of defined benefit plans, as measured by the pension dummy, further raise the probability of being retired. Finally, with regard to the probability of retiring earlier than planned, a change in defined contribution wealth increases the probability, but pension coverage per se reduces it. That is, those with pensions tend to be more accurate planners than those without.
\end{abstract}




\section{Background}

Until the mid-1980s, the age at which people retired had declined for decades. In the mid-1980s, the decline ceased. Between 1985 and 2002, the retirement age for men held steady (Figure 1). ${ }^{1}$ At about the same time as the break in the retirement-age trend, the nature of pension coverage began to shift dramatically, even though the percentage of the workforce covered by an employer-sponsored pension remained virtually unchanged until recently when it has started to decline. ${ }^{2}$ Among those lucky enough to be covered by a pension, the portion with only a defined contribution plan increased from about 20 percent in 1981 to nearly 60 percent today (Figure 2).

Defined benefit and defined contribution plans are structured quite differently. Under traditional defined benefit plans, workers accrue benefits over their work life and receive a life annuity at retirement, which guarantees them benefits for as long as they live. The benefit is typically calculated as a dollar amount per year of service, or as a percentage of final salary for each year of service. In the event the company cannot fulfill its pension promise, workers' benefits (up to a maximum of $\$ 3,699$ per month in 2004 for workers retiring at 65) are insured through the Pension Benefit Guaranty Corporation(PBGC).

Defined contribution plans - most notably 401(k)s - look very different. They are like savings accounts. The employer and employee both contribute to the account, employees control account assets, and can allocate funds to match their tolerance for risk. Defined contribution assets are also portable, which means that mobile workers can take their pensions with them as they move from job to job. On the other hand, the worker bears the investment risk. So, if the stock market booms, they gain; if it slumps, they lose. Defined contribution plans generally do not pay annuities; rather, they offer participants a lump sum. Therefore, participants bear the interest rate risk at retirement. The PBGC does not insure benefits.

What difference does it make whether people are covered by a defined benefit or a defined contribution plan, assuming that they have the same level of wealth under either plan?

\footnotetext{
${ }^{1}$ For older women, labor force participation rates were flat until the mid-1980s. The trend toward earlier retirement experienced by all older workers during this period was offset by the increased labor force participation of married women. Since the mid-1980s, the labor force participation rates of women have increased dramatically (Burtless and Quinn, 2002). Today, the average retirement age of women is about 61 years based on authors' calculations of data from the Bureau of Labor Statistics (BLS, 2003).

${ }^{2}$ In 1979,51 percent of non-agricultural wage and salary workers in the private sector aged 25-64 participated in a pension; in 2002, that number was 46 percent.
} 
In both cases, they are going to get benefits, and those bene fits will enable them to retire earlier than they would have been able to without a pension.

The story is more complicated, because the two pensions have different financial incentives, different ways of paying benefits, and different types of risks. First, provisions in many traditional defined benefit plans offer a significant subsidy for early retirement, while 401(k) plans are neutral with respect to retirement age. Some argue that the early retirement subsidy was developed to encourage workers, who might be tempted to stay on too long, to retire when their productivity declines (Lazear 1983). Others believe that the provision was pushed by labor unions who wanted to let their people out early. In any event, companies offer benefits at an early retirement age, such as 55, that are not adjusted sufficiently to reflect the fact that retirees will receive benefits for 10 years longer than if they retired at age 65 .

Defined contribution plans operate very differently. A worker's accumulated pension wealth changes each year by contributions to the account and the earnings on accumulated assets. Pension wealth continues to rise even if contributions are zero (assuming earnings on assets are positive). The only aspect of a defined contribution or 401(k) plan that might affect retirement age is the constraint, imposed by the government, that funds cannot be withdrawn without a penalty until the worker reaches age 59 1/2. Otherwise, 401(k) plans should not encourage retirement at any particular age.

Figure 3 shows accrued pension benefits as a multiple of annual pay at different ages for a traditional defined benefit plan and a cost-equivalent defined contribution plan. In each case, workers retiring at 65 would accumulate benefits equal to four times their final salary. In the case of defined contribution plans, the more the person works, the greater total retirement benefits are relative to earnings. Thus, the pension provides no incentive to retire at a particular age. In contrast, benefits relative to annual pay in a traditional defined benefit plan jump sharply at 55, the early retirement age, because of the lack of an actuarially fair adjustment. The disappearance of the subsidy provides a powerful incentive to retire prior to the normal retirement age in the plan. ${ }^{3}$

\footnotetext{
${ }^{3}$ Considerable research exists on retirement incentives in defined benefit plans. An early study by Kotlikoff and Wise (1989) documented the incentives in a single plan for a Fortune 500 company and in a nationally representative cross section of plans. Stock and Wise (1990); Lumsdaine, Stock, and Wise (1992); and Samwick (1998) have done similar studies. Researchers have taken different approaches to characterizing the incentives in the plans. Stock and Wise developed an "option value" measure to reflect the utility gains or losses from postponing retirement, while Coile and Gruber (2000) introduced a somewhat simpler concept of "peak difference" of pension
} 
The second factor that may influence retirement is the nature of the benefit payment. Traditional defined benefit plans offer an annuity - that is, a stream of payments - while defined contribution plans typically pay a lump sum. Individuals may perceive an expected flow of income for life differently than a lump-sum of equal value. For example, individuals may be reluctant to spend their $401(\mathrm{k})$ balances in the hope of leaving a sizable bequest. Or they may spend down their wealth too slowly in order to insure that they do not exhaust their assets before they die. For these reasons, when pension payments are in the form of a lump sum rather than an annuity, individuals may desire a higher level of wealth in retirement to maintain an equivalent level of consumption. Therefore, we might expect to see a higher retirement age associated with lump-sum distributions from defined contribution plans.

Finally, individuals may react differently to levels of retirement wealth depending on their sense of the reliability of the amount. For example, it is possible for 401(k) balances to change dramatically in a short period of time, which can make it difficult for individuals to reliably predict how much income they can expect to receive from the account. In addition, upon receiving a lump sum at retirement, individuals must decide how to invest the money and then estimate the interest they will receive on their investments. The presence of this investment uncertainty may cause some individuals to err on the side of caution and stay in the workforce longer than if they had a more predictable income stream from a defined benefit plan. ${ }^{4}$

In short, three aspects of defined contribution plans would be expected to lead to later retirement - the absence of explicit early retirement incentives, the payment of a lump sum rather than an annuity, and the investment and interest rate risk associated with these plans.

\section{The Effect of Pension Type on Expected Retirement Age}

The first step in this analysis is to use the HRS to see how pension coverage affects respondents' expected retirement age. ${ }^{5}$ The theory says that people with pension wealth of any

\footnotetext{
wealth accruals.

${ }^{4}$ It is important to note that, while accrued benefits under defined benefits plans are more certain than accrued benefits under defined contribution plans, defined benefit pensions are not free of risk. The PBGC guarantee on accrued benefits is capped and future accruals could be affected by plan changes. Of course, defined contribution plans carry similar risks with respect to future accruals.

${ }^{5}$ The HRS is a nationally-representative data set of about 12,650 individuals from about 7,600 households. This study began in 1992 by interviewing people age 51-61 and their spouses (regardless of age). The survey was readministered in 1994, 1996, 1998, 2000, and 2002. The HRS is conducted by the Institute for Social Research (ISR)
} 
sort should retire earlier than those without and that those with a defined benefit plan should retire even earlier because of the retirement incentives, payment in the form of annuity, and reliability of accrued benefits. Indeed, tabulations from the first wave of the HRS show that those currently with no pension expect to retire at age 64.4, with a defined contribution plan only at age 63.5 , with a defined benefit plan only at 62.5, and with both a defined benefit and defined contribution plan at $62.2 .^{6}$

To isolate the pension effect, it is necessary to control for many other factors that could also influence retirement. Being female, married, or in poor health, owning one's home, having retiree health insurance provided by one's employer, and having a physically-demanding job should all lead to earlier retirement. ${ }^{7}$ In contrast, having more education or being self-employed would be expected to delay retirement. The impact of higher wages is theoretically ambiguous. On the one hand, higher wages allow workers to achieve their retirement savings goal in fewer years and retire earlier; on the other hand, the higher level of compensation for each year worked may encourage workers to stay in the labor force longer.

We estimate an equation for HRS respondents who were working at the time of the wave one interview. Limiting the sample to those who are currently employed reduces the number from 12,650 to 8,370 (see Table 1). Missing information - primarily for benefits under defined benefit plans, defined contribution plans and Social Security and for expected retirement age further reduces the sample to 4,955 . $^{8}$ Whenever possible both the respondents' retirement expectations and the independent variables are defined as of 1992. For a few individuals information on expected retirement age was taken from later waves, and some information on expected Social Security benefits was taken from later waves in order to avoid significantly reducing the sample size.

While coverage is entered for the individual worker, defined benefit, defined contribution, and Social Security wealth are household numbers. The reasoning is that

at the University of Michigan and is made possible by funding from the National Institute on Aging. More information is available at the ISR website: http://hrsonline.isr.umich.edu/.

${ }^{6}$ Pension status (having a defined benefit or defined contribution plan) is based only on the worker's current job. ${ }^{7}$ Although our specification addresses the issue of spousal influences by including household-level pension and financial variables, the model could be enhanced by estimating a system of equations in which spouses jointly determine the retirement decision (see Coile, 2003).

${ }^{8}$ Another 652 respondents were missing pension wealth information for their previous jobs. The equation was estimated both with and without these individuals, and the results were virtually identical. Since their inclusion did not change the results, we kept them in the sample. 
retirement incentives apply to the individual but once the wealth has been accumulated it becomes part of the household's pile of assets. Social Security wealth is based on self-reported current or expected benefits. ${ }^{9}$ Defined benefit wealth comes from the Peticolas-Steinmeier numbers posted on the HRS website; these numbers are derived from the restricted pension data provided by the employer. Defined contribution wealth is based on self-reported estimates for 1992 where available. If defined contribution wealth is reported only in subsequent waves, the post-1992 number is reduced by assumed earnings and employer and employee contributions to arrive at the 1992 figure. ${ }^{10}$ Total financial wealth is equal to the value of assets in stocks, bonds, checking accounts, certificates of deposit, and any other account, minus household debt. All wealth variables are measured in $\$ 10,000$ increments. See Table 1 for sample means and means for the HRS population.

Most other variables are dichotomous indicators. For example, retiree health insurance is equal to one if either the respondent's employer provides health insurance in retirement or the respondent is covered by his spouse's retiree health insurance and zero otherwise. The exceptions to indicator variables are wages and age. Wages are measured in 1992 dollars. Age is entered continuously and with a spline because people are likely to respond differently after 55 , the age for early retirement under many private pension plans. ${ }^{11}$

The coefficient estimates and t-statistics for independent variables are presented in Table 2. Both the pension variables and the other variables, such as age, gender, health, education, marital status and spouse working, self-employed status, and homeownership, have the expected sign, and virtually all the coefficients are statistically significant.

The goal is to isolate the effect of pensions on expected retirement age. This exercise appears in Table 3. The first step is to calculate the base retirement age before the effect of either the pension or socio-economic variables. The base retirement age is equal to the constant

\footnotetext{
${ }^{9}$ Although the HRS provides administrative data on Social Security covered earnings and projected benefits, we calculated Social Security wealth using self-reported current or expected Social Security benefits to increase our sample. We had access to the administrative data for this project and estimated equations using both values for Social Security wealth, and the results were quite similar.

${ }^{10}$ Earnings in each year are equal to a weighted average of the change in the Standard and Poor's 500 index and the yield on the 10-year Treasury, where the weights reflect the proportion of equities and non-equities in the defined contribution portfolios as reported in the Federal Reserve's Flow of Funds. Employee and employer contributions are based on self-reported values. If contribution rates are missing then 6 percent for employee and 3 percent for employer contribution rates were assigned.

${ }^{11}$ Age plays an important role in this equation because older individuals in the sample have a more limited set of options for expected retirement ages than younger individuals. The continuous age variable serves as an attempt to control for this sample selection effect.
} 
(56.7) plus the coefficient on the Age variable (0.16) multiplied by the average age for the sample, and the coefficient on Age 55 (0.30) multiplied by the difference between a person's actual age and 55 if age is greater than 55. So for a person age 54.5, the base retirement age is 65.3 years. $^{12}$ This number shows up as the first line of Table 3.

The next step is to estimate the effect of pension coverage on the expected retirement age. First, the impact of Social Security wealth reduces the expected retirement age by 0.4 years. This calculation involves multiplying the Social Security coefficient (0.024) by 17.7 since the wealth amounts are entered in $\$ 10,000$ increments and the average Social Security wealth for this cohort is $\$ 176,797$. Similar calculations for defined benefit wealth $\$ 159,631$ (in 1992) and defined contribution wealth $\$ 66,863$ (in 1992) show that these variables reduce the retirement age by 0.6 years and 0.1 years, respectively. The next row in Table 3 shows the effect of the pension characteristics over and above the wealth effect. Taking the wealth and pension characteristics together, Table 3 shows for a worker with no pension coverage, the expected retirement age is 64.9 years. For a typical worker with a defined contribution pension, the expected retirement age is 64.6; and for a typical worker with a defined benefit plan it is $63.2-$ about one year earlier.

As just noted, two separate aspects of defined benefit coverage are responsible for this significant reduction in the retirement age: (1) the amount of defined benefit wealth and (2) the general characteristics associated with such plans (i.e., early retirement incentives, lifelong benefits, and reduced investment risk). First, the amount of an individual's defined benefit plan wealth moves the retirement age forward by 0.6 years. For individuals with more defined benefit wealth, the expected retirement date would be even earlier; for those with less than average wealth, the date would be later. Then, the characteristics of defined benefit plans move up an individual's expected retirement date by 1.1 years. $^{13}$

Not surprisingly, the situation for individuals with defined contribution pension coverage is quite different. Overall, their expected retirement age is only 0.3 years earlier than for those without any pension coverage. Pension wealth is responsible for a slight drop in the expected

\footnotetext{
12 The result is consistent with the expected retirement age for working individuals aged 50 and over (Moore, 2003). Not surprisingly, the value is higher than the expected retirement age for the population generally.

${ }^{13}$ This implication inherently assumes that specific types of individuals do not self select into different kinds of pension plans. If they did, the coefficient on plan type might be picking up differences in the types of individuals, rather than differences in plan characteristics. Friedberg and Webb (2000) conclude that this self selection issue does not appear to be a problem.
} 
retirement age, and the general characteristics of defined contribution plans adds a further fraction. Table 3 implies that those in their 50s and 60s who are covered by a defined benefit plan expect to retire more than one year earlier than those covered by a defined contribution plan.

\section{The Effect of Pensions on the Probability of Actual Retirement}

This section shifts the focus from respondents' plans to retire to their actual retirement experience. Instead of taking the independent variables as a snapshot at a specific point in time, this approach allows factors, such as health status, wealth, and spouses' work status, to change over time and influence the retirement decision. It also allows a more complete description of the retirement incentives in pension plans.

The sample consists of all workers in each of the six waves of the HRS. The dependent variable is equal to one if the respondent leaves his job voluntarily from one wave to the next and retires fully. That is, leavings due to layoffs or plant closings are not considered retirement. To be clear, the sample starts with only individuals who are working in 1992. The first retirement observation is 1994; if the person has retired, the dependent variable is equal to one, if not zero. Once people retire, they are out of the sample. The 1996 pool consists of those who were working in 1994; again those who have retired by 1996 are assigned a one; the others a zero. And so the process continues through 2002. Thus, the exercise does not address the probability of a random person in the population being out of the labor force; rather it looks at the probability of a person who was previously working retiring.

The pooled regression makes it possible to characterize the pension variables more fully than the snapshot regression for expected retirement age. After all, it is not just the existence of the pension and the pension wealth that affects retirement, but also the amount that respondents can earn by working an additional year. As discussed earlier, the accrual pattern under defined benefit and defined contribution plans are very different. In defined benefit plans accruals increase sharply at some point and then become negative. In defined contribution plans, accruals are positive as long as earnings on assets are positive. 
Other researchers have used the HRS to examine the effect of pension type on the retirement decision. Most recent is a paper by Friedberg and Webb (2003). Our analysis in this portion of the paper differs in four ways. First, our sample includes all working individuals, not just those covered by a pension. Second, we define working to include part-time workers and the self-employed in addition to those working full time. Third, we include all six waves of the HRS. Finally, we take a different route in terms of analyzing the impact of pensions.

Researchers have experimented with several ways of introducing the retirement accrual variable into regression equations. Stock and Wise (1990) proposed an "option value" measure that reflects the gain in utility from postponing retirement and gaining access to future accruals. This model is very difficult to implement, however. Coile and Gruber (2000), looking at incentives in the Social Security program, introduced the simpler notion of "peak value" - as long as the current value of pension wealth falls short of the potential peak value, workers have an incentive to stay on the job.

We have chosen simply to enter annual pension accrual as the incentive variable. It allows us to treat defined benefit and defined contribution plans in a parallel fashion. And it seems to us that it more accurately represents the thinking process of the typical worker, who we believe is unlikely to look forward enough to compare peak value with current pension wealth. For completeness, however, we also try the peak value measure and find the results are quite consistent.

Given the binary nature of the dependent variable, the model is estimated using a probit; the results are presented in Table 4. The values reported in the table are the change in the probability of being retired given a one-unit change in a continuous variable or the shift in a dichotomous variable from zero to one. For example, if the employee has a retiree health insurance, the probability of retiring increases by almost 4 percentage points - all else equal. If the amount of wealth in a defined benefit plan increases by $\$ 10,000$, the probability of retiring rises by 0.1 percent age points.

The first equation (Table 4) repeats the equation used to estimate expected retirement age in 1992. As in the earlier equation, pension coverage is represented by an indicator to identify those covered by a defined benefit plan and by a defined contribution plan and a wealth variable for each type of pension. The results are mostly consistent with those for expected retirement. The probability of retiring is positively related to Social Security, defined contribution, and 
defined benefit wealth, and the defined benefit coverage indicator has a large positive and statistically significant impact on the probability of retiring. The results for defined contribution plans differ, however. The indicator variable suggests a negative effect - that is it discourages retirement. All the socio-economic variables have the same effect as they did in the equation for expected retirement age. Retiree health insurance, poor health, being female, having a physically demanding job and owning a home all increase the probability of retiring. Having a college education, living with a working spouse, and being self-employed all reduce the probability of retirement.

The next equation (Table 4, Eq. 2) introduces directly into the equation the separate effects of the two types of pension plans. The first variable, which reflects the retirement incentives, is the increase in pension wealth that the worker would gain by staying an additional year. In the case of defined benefit plans, the accrual is the change in defined benefit wealth. In the case of defined contribution plans, the accrual is the employer's and employee's contributions. The return on defined contribution assets is entered separately because the respondent receives this amount regardless of labor force status. The coefficients in Equation 2 are consistent with the theory. The probability of being retired is negatively related to the level of accrual, but positively related to the return on defined contribution assets.

The conclusion that emerges from this section is that pension coverage and type is an important determinant not only of expected retirement age but also of actual retirement age. People covered by any type of plan will retire earlier than those not covered, and people with a defined benefit plan will retire earlier than those with a defined contribution plan. In defined benefit plans, pension wealth, and pension characteristics play an almost equal role in encouraging retirement. In defined contribution plans, the primary retirement incentive is the wealth effect. Defined contribution coverage itself appears to deter retirement, as do accruals.

\section{Explaining the Probability of Earlier-than-Planned Retirement}

This final section explores the extent to which pensions explain the difference between expected and actual retirement - particularly why some people retire earlier than expected. Surveys consistently show that people plan to retire around age 65 , but the median actual retirement age is 62 (Figure 4). The question is why? 
The analysis starts with all workers in 1992 and identifies those who have retired earlier than expected. People who are in the labor force in 2002 fall into two categories: those who thought that they would have retired by 2002 and those who had planned to keep working beyond 2002. The entire first group is included in the sample because it is clear that they are working longer than expected; those in the second group are included only to the extent that their current age equals their expected retirement age because the others still have the potential to retire early. The dependent variable is set equal to 1 if the person's actual retirement age was earlier than their expected retirement age in 1992; zero otherwise.

The explanatory variables include those from the original 1992 regression of expected retirement age and new "shock" variables. The original variables are female, age, college, poor health, retiree health insurance, self employment status, and indicators for the defined benefit and defined contribution coverage. The "shock" variables - deterioration in health status, retirement of worker's spouse, change in financial wealth and defined contribution assets, and job change are likely reasons why people might change their retirement plans.

The results show that retiring earlier than planned is correlated with the original variables, the shock variables, and pension coverage (see Table 5). Having "poor" or "fair" health in 1992 increases the probability of retiring earlier than expected, probably because those with health problems underestimate the negative impact of bad health on their ability to work later in life. A deterioration in health status increases the probability of retiring earlier by 14 percent. ${ }^{14}$ Similarly, consistent with recent work on joint decision making, the probability of retiring early rises if the worker's spouse retires. Also as expected, an increase in financial wealth or defined contribution assets have positive impact on the probability of retiring earlier. ${ }^{15}$ People who switched jobs after 1992 are less likely to retiree earlier than expected. One possible explanation is that people who leave their main jobs may switch to a "bridge" job that better fits their life style as they approach retirement and thereby allows them to stay in the work force longer. Or people may have been forced to leave from their career job with inadequate retirement

\footnotetext{
${ }^{14}$ Deterioration reflects a decline in the respondent's assessment from "excellent", "very good", or "good" to "fair"/"poor", or from "fair" to "poor."

${ }^{15}$ We tried changes in defined benefit and Social Security wealth. Both of them had positive coefficients that were insignificant. The reason is that changes in defined benefit wealth and Social Security wealth are anticipated and should not induce any deviation from the expectation of retirement age.
} 
recourses and were forced to stay in the labor force longer. ${ }^{16}$ It is worth noticing that college education and being female do not affect the probability of retiring earlier than planned.

Retiring earlier than planned is also negatively related to pension coverage. Similarly, the probability of retiring earlier decreases for the people that have insurance in retirement. It is likely that workers who have employer-sponsored pension and retiree health insurance are in a better position to plan their retirement more accurately than those without benefits.

\section{Conclusion}

The HRS provides a wonderful opportunity to explore the effect of pensions on the whole retirement process. Pensions are complicated institutions, yet in virtually every instance, the HRS results show pension variables having the predicted effect on expected and actual retirement patterns. The first part of the analysis looked at expected retirement age for those working in 1992. As predicted, the presence of pension wealth lowers the expected retirement age for those with pensions compared to those without. In addition, the incentives for early retirement under defined benefit plans have an additional large - more than a year - and statistically very significant effect on reducing the expected age further. The additional effects from defined contribution plans are only marginally significant and quite small.

The second part of the analysis considered the effects of pensions on the probability of retiring in one wave given the respondent was working in the previous wave. Here pensions enter in four separate ways. First, consistent with theory, pension wealth increases the probability of retiring. Second, the early retirement incentives in defined benefit plans (as captured by the pension coverage dummy) further increase the probability of retirement. Third, the higher the earnings on the defined contribution assets, the more likely workers are to retire. Finally, the greater the accruals in both defined contribution and defined benefit plans, the lower the probability of retirement. In short, pension wealth encourages retirement but the incentives are much stronger for defined benefit than defined contribution plans.

\footnotetext{
${ }^{16}$ Selection can be an alternative explanation. Some people might change their attitude about working as they approach retirement as a result of some random shock and have an incentive to find a job that matches their life style.
} 
The results of the third exercise, which explores the reasons for retiring earlier than planned - are perhaps the most interesting. In this case, initial characteristics and shock variables - including the change in defined contribution wealth - are important variables in explaining changes in retirement plans. Pensions are also important here: pension coverage reduces the likelihood of retiring earlier than planned. The intuition is that people covered by pensions are in the position to better plan their withdrawal from the labor force.

The implications going forward are threefold. First, the shift from defined benefit to defined contribution plans will eliminate much of the incentive for early retirement. Second, the apparent decline in pension coverage will mean that a smaller percent of the work force will have the pension wealth that enables people to retire. Finally, the decline in pension coverage will make it more difficult for people to plan when they will be able to leave their jobs. 


\section{References:}

Benitez-Silva, Hugo and Debora S. Dwyer. 2003. "What to Expect When You Are Expecting Rationality: Testing Rational Expectations Using Micro Data." Working Paper 2003-037. Ann Arbor, MI: University of Michigan Retirement Research Center.

Burtless, Gary and Joseph F. Quinn. 2002. "Is Working Longer the Answer for an Aging Workforce?" Issue in Brief 11 (December). Chestnut Hill, MA: Center for Retirement Research at Boston College.

Coile, Courtney and Jonathan Gruber. 2000. "Social Security Incentives for Retirement." NBER Working Paper 7651.

Dwyer, Debra S. 2001. "Retirement Planning for Retirement: The Accuracy of Expected Retirement Dates and the Role of Health Shocks." Working Paper 2001-08 (September). Chestnut Hill, MA: Center for Retirement Research at Boston College.

Friedberg, Leora and Anthony Webb. 2000. "The Impact of 401(k) Plans on Retirement." Discussion Paper 2000-30. University of California, San Diego Department of Economics.

Gustman, Alan L. and Thomas L. Steinmeier. 1999. "Pension and Retiree Health Benefits in Household Wealth: Changes from 1969 to 1992.” NBER Working Paper 7320.

Kotlikoff, Laurence J. and David Wise. 1989. “Employee Retirement and a Firm's Pension Plan.” NBER Working Paper 2323.

Lazear, Edward 1983. "Pensions as Severance Pay." In Financial Aspects of the United States Pension System, edited by Zvi Bodie and John Shoven. Chicago, IL: University of Chicago Press.

Lumsdaine, Robin, James Stock, and David Wise. 1992. "Pension Plan Provisions and Retirement: Men \& Women, Medicare and Models.” NBER Working Paper 4201.

Moore, David W. 2003. "Retirement Income Biggest Financial Worry for Americans." The Gallup Organization.

Munnell, Alicia H., Kevin E. Cahill, and Natalia A. Jivan. 2003. "How has the Shift to 401(k)s Affected the Retirement Age?" Issue in Brief 13 (September). Chestnut Hill, MA: Center for Retirement Research at Boston College.

Munnell, Alicia H., and Annika Sundén. 2004. Coming Up Short: The Challenge of 401( $k$ ) Plans. Brookings Institution Press.

Samwick, Andrew. 1998. "New Evidence on Pensions, Social Security, and the Timing of Retirement.” Journal of Public Economics Vol. 70, pp. 207-36.

Stock, James H. and David A. Wise. 1990. "Pensions, the Option Value of Work, and Retirement.” Econometrica, Vol. 58, No. 5 (September), pp. 1151-1180. 
Table 1: Characteristics of Workers by Pension Coverage in Current Job, HRS 1992

\begin{tabular}{|c|c|c|c|c|}
\hline \multirow[b]{2}{*}{ Variable } & \multicolumn{2}{|c|}{ HRS Universe } & \multicolumn{2}{|c|}{ Working in 1992} \\
\hline & Mean & $\begin{array}{l}\text { Standard } \\
\text { Deviation }\end{array}$ & Mean & $\begin{array}{l}\text { Standard } \\
\text { Deviation }\end{array}$ \\
\hline Number of workers & 12652 & & 4955 & \\
\hline Expected retirement age & $63.4^{17}$ & 4.49 & 63.4 & 4.36 \\
\hline Defined benefit wealth (HH) & $\$ 166,278$ & $\$ 183,375$ & $\$ 159,631$ & $\$ 177,225$ \\
\hline Percent with DB plan & 52.2 & - & 61.4 & - \\
\hline Defined contribution wealth $(\mathrm{HH})$ & $\$ 61,774$ & $\$ 118,214$ & $\$ 66,863$ & $\$ 128,242$ \\
\hline Percent with DC plan & 33.1 & - & 45.2 & - \\
\hline Social Security wealth (HH) & $\$ 178,847$ & $\$ 105,988$ & $\$ 176,797$ & $\$ 106,019$ \\
\hline Total financial wealth $(\mathrm{HH})$ & $\$ 51,572$ & $\$ 180,133$ & $\$ 53,411$ & $\$ 184,427$ \\
\hline Wage & $\$ 18.8$ & 283.0 & $\$ 17.7$ & 153.3 \\
\hline Retiree health insurance & 0.48 & 0.500 & 0.57 & 0.495 \\
\hline Age & 55.3 & 5.664 & 54.6 & 5.14 \\
\hline Female & 0.54 & 0.499 & 0.51 & 0.50 \\
\hline Fair or poor health & 0.22 & 0.416 & 0.11 & 0.315 \\
\hline College education & 0.17 & 0.380 & 0.22 & 0.415 \\
\hline Married & 0.81 & 0.391 & 0.82 & 0.38 \\
\hline Married, spouse working & 0.54 & 0.499 & 0.61 & 0.488 \\
\hline Self-employed & 0.12 & 0.327 & 0.139 & 0.35 \\
\hline Physically-demanding job & 0.27 & 0.443 & 0.38 & 0.487 \\
\hline Own a home & 0.82 & 0.387 & 0.87 & 0.332 \\
\hline
\end{tabular}

${ }^{17}$ Defined for 7438 observations only. 
Table 2: Coefficients from Equation Explaining Expected Retirement Age, HRS 1992

\begin{tabular}{lrc}
\hline Variable & Coefficient & t-statistic \\
\hline Pension coverage & & \\
$\quad$ Defined benefit & -1.06 & -8.77 \\
$\quad$ Defined contribution & -0.16 & -1.33 \\
Pension wealth & & \\
$\quad$ Defined benefit & -0.04 & -6.60 \\
$\quad$ Defined contribution & -0.016 & -1.99 \\
$\quad$ Social Security & -0.024 & -2.92 \\
& & \\
Total financial wealth & -0.01 & -1.53 \\
Wage & -0.0006 & -5.08 \\
Retiree health insurance & -0.75 & -6.14 \\
Age & 0.16 & 6.11 \\
Age 55 & 0.30 & 6.68 \\
Female & -0.57 & -5.00 \\
Fair or poor health & -0.80 & -4.76 \\
College education & 0.89 & 5.79 \\
Married & 0.003 & 0.02 \\
Married, spouse working & 0.18 & -2.12 \\
Self-employed & & -5.52 \\
Physically-demanding job & & 40.23 \\
Owns a home & & \\
Constant & & \\
R-squared: 0.2134 & & \\
Number of Observations: 4,955 & & \\
\hline
\end{tabular}


Table 3: Expected Retirement Ages, by Pension Coverage Characteristics

\begin{tabular}{|c|c|c|c|}
\hline & $\begin{array}{c}\text { No pension } \\
\text { coverage }\end{array}$ & $\begin{array}{c}\text { DB pension } \\
\text { coverage }\end{array}$ & $\begin{array}{c}\text { DC pension } \\
\text { coverage }\end{array}$ \\
\hline Base retirement age & 65.3 & 65.3 & 65.3 \\
\hline Social Security wealth & -0.4 & -0.4 & -0.4 \\
\hline Pension wealth & & -0.6 & -0.1 \\
\hline Pension characteristics & & -1.1 & -0.2 \\
\hline & & & \\
\hline Expected retirement age & 64.9 & 63.2 & 64.6 \\
\hline
\end{tabular}

Source: Authors' calculations based on coefficients of equation reported in Table 2 and wealth values reported in Appendix Table 1. 
Table 4. Marginal Effects from Probit Equation Explaining Actual Retirement Age, HRS 1992-2002

\begin{tabular}{|c|c|c|c|c|c|}
\hline \multirow{3}{*}{\multicolumn{2}{|c|}{ Variable }} & \multicolumn{4}{|c|}{$d F / d x$} \\
\hline & & \multicolumn{2}{|c|}{ Eq. 1} & \multicolumn{2}{|c|}{ Eq. 2} \\
\hline & & Coefficient & Z-statistic & Coefficient & Z-statistic \\
\hline \multicolumn{2}{|c|}{ Pension coverage: Defined benefit } & 0.038 & 6.82 & 0.039 & 6.89 \\
\hline & Defined contribution & -0.022 & -3.91 & -0.018 & -2.87 \\
\hline \multirow[t]{3}{*}{ Pension wealth: } & Defined benefit & 0.001 & 5.52 & 0.001 & 5.16 \\
\hline & Defined contribution & 0.001 & 3.91 & 0.0004 & 2.54 \\
\hline & Social Security & 0.001 & 5.66 & 0.001 & 5.66 \\
\hline \multirow[t]{2}{*}{ Pension accruals: } & Defined benefit & - & - & -0.003 & -1.25 \\
\hline & Defined contribution & - & - & -0.033 & -1.62 \\
\hline \multicolumn{2}{|c|}{ Return on defined contribution assets } & - & - & 0.001 & 1.16 \\
\hline \multicolumn{2}{|c|}{ Total financial wealth } & -0.0001 & -1.44 & -0.0001 & -1.25 \\
\hline \multicolumn{2}{|l|}{ Wage } & 0.00001 & 0.88 & .0001 & 0.91 \\
\hline \multicolumn{2}{|c|}{ Retiree health insurance } & 0.037 & 7.28 & 0.038 & 7.34 \\
\hline \multicolumn{2}{|l|}{ Age } & 0.009 & 5.95 & 0.009 & 5.96 \\
\hline \multicolumn{2}{|l|}{ Age 55} & 0.018 & 8.05 & 0.018 & 7.96 \\
\hline \multicolumn{2}{|l|}{ Age 62} & -0.026 & -12.33 & -0.026 & -12.21 \\
\hline \multicolumn{2}{|l|}{ Female } & 0.014 & 2.75 & 0.014 & 2.66 \\
\hline \multicolumn{2}{|c|}{ Fair or poor health } & 0.085 & 10.95 & 0.085 & 10.93 \\
\hline \multicolumn{2}{|l|}{ College education } & -0.024 & -4.12 & -0.024 & -4.04 \\
\hline \multicolumn{2}{|l|}{ Married } & 0.008 & 1.11 & 0.008 & 1.08 \\
\hline \multicolumn{2}{|c|}{ Married, spouse working } & -0.027 & -5.00 & -0.027 & -5.01 \\
\hline \multicolumn{2}{|l|}{ Self-employed } & -0.024 & -3.61 & -0.023 & -3.57 \\
\hline \multicolumn{2}{|c|}{ Physically-demanding job } & 0.008 & 1.65 & 0.008 & 1.63 \\
\hline \multicolumn{2}{|l|}{ Home ownership } & 0.011 & 1.53 & 0.011 & 1.52 \\
\hline \multicolumn{2}{|c|}{$\begin{array}{l}\text { Pseudo R-squared: } \\
\text { Number of Observations : } 19,343\end{array}$} & 0.1111 & & 0.1115 & \\
\hline
\end{tabular}


Table 5. Marginal Effects from Probit Equation Explaining the Probability of Retiring Earlier than Planned, HRS 1992-2002

\begin{tabular}{|c|c|c|}
\hline \multirow[t]{2}{*}{ Variable } & \multicolumn{2}{|c|}{ Retired early } \\
\hline & $d F / d x$ & Z-statistics \\
\hline \multicolumn{3}{|l|}{ Original Variables } \\
\hline Age & -0.026 & -9.65 \\
\hline Female & 0.009 & 0.41 \\
\hline Fair or poor health & 0.129 & 3.56 \\
\hline College education & 0.014 & 0.53 \\
\hline Self-employed & -0.035 & -1.03 \\
\hline Retiree health insurance & -0.036 & -1.62 \\
\hline \multicolumn{3}{|l|}{ "Shock" variables } \\
\hline Change in he alth status & 0.144 & 4.13 \\
\hline Change in spouse's status & 0.061 & 2.41 \\
\hline $\begin{array}{l}\text { Change in defined contribution } \\
\text { wealth }\end{array}$ & 0.001 & 1.44 \\
\hline Change in financial wealth & 0.001 & 1.93 \\
\hline Switched the job & -0.159 & -6.63 \\
\hline \multicolumn{3}{|l|}{ Pension coverage } \\
\hline Defined benefit & -0.037 & -1.64 \\
\hline Defined contribution & -0.033 & -1.46 \\
\hline $\begin{array}{l}\text { Pseudo R-squared: } 0.1063 \\
\text { Number of Observations : } 1,710\end{array}$ & & \\
\hline
\end{tabular}


Figure 1: Average Retirement Age of Men, 1910 - 2002

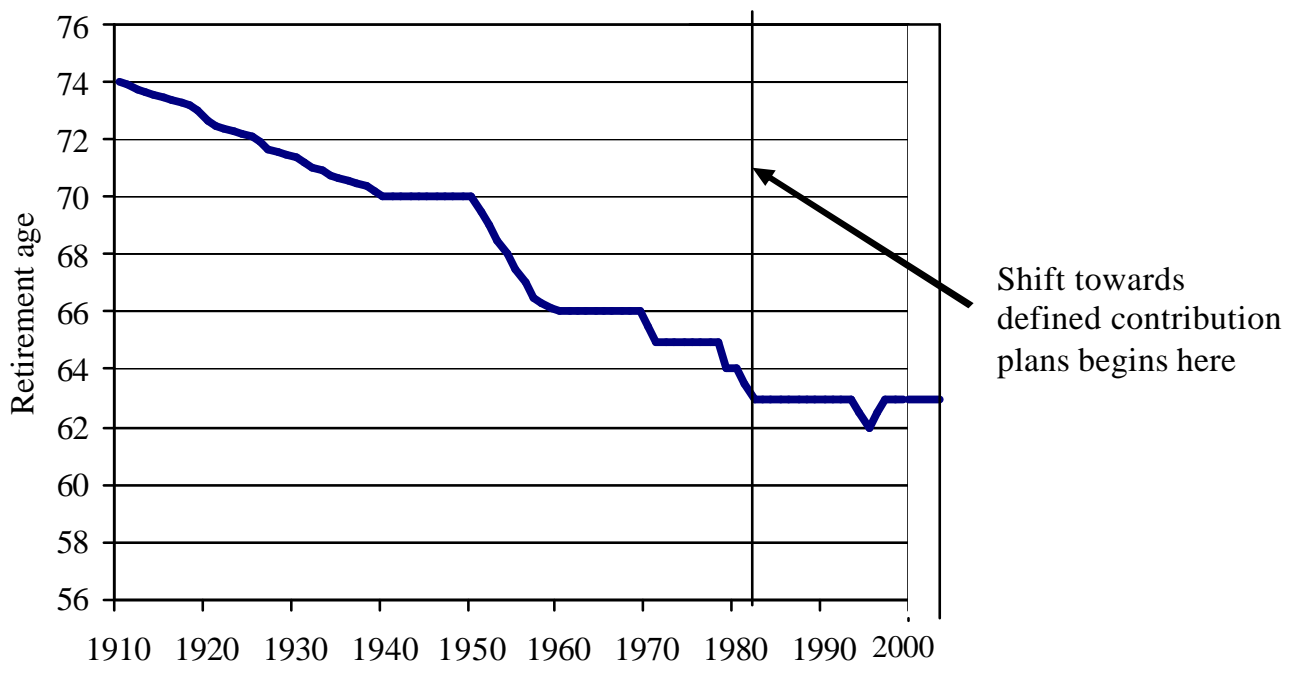

Source: Burtless and Quinn (2002). "Is Working Longer the Answer for an Aging Workforce?" Issue in Brief 11 (December); authors' calculations using Bureau of Labor Statistics (2003). 
Figure 2. Percent of Wage and Salary Workers with Pension Coverage by Type of Plan, 1981-2001

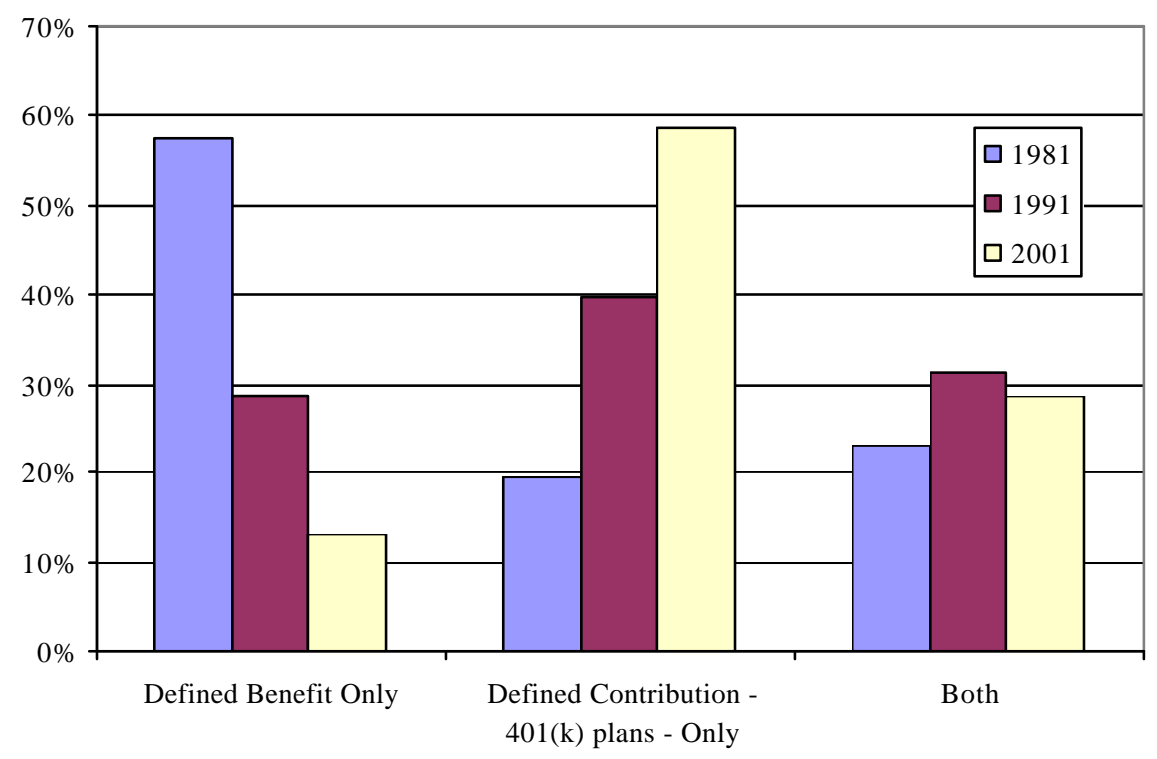

Source: 1981, 1991: U.S. Department of Labor (2002). Private Pension Plan Bulletin, Abstract of 1999 Form 5500 Annual Reports, Historical Table E4; 2001: Own Calculations using the 2001 Survey of Consumer Finances from the Board of Governors of the Federal Reserve System. 
Figure 3. Accrued Pension Benefits in a Traditional Defined Benefit Plan and Defined Contribution Plan as a Multiple of Annual Pay

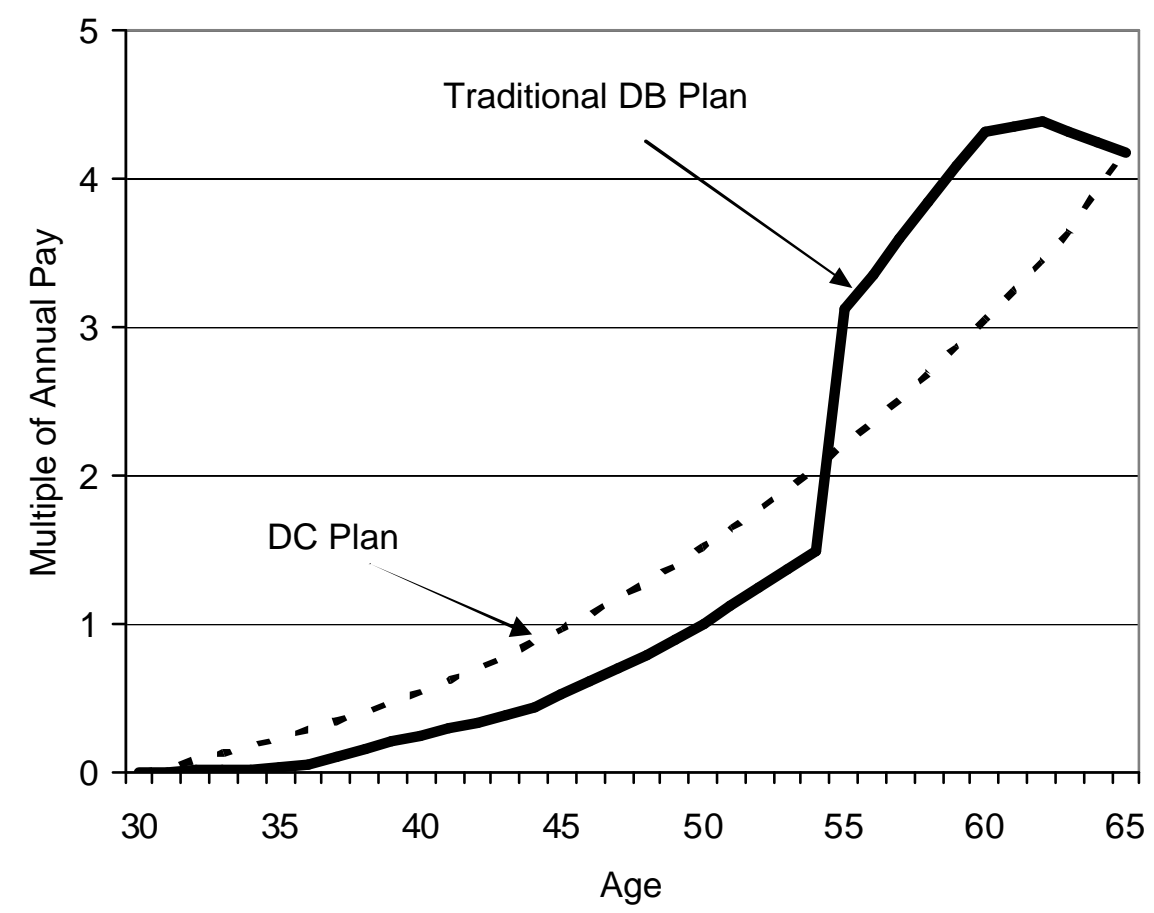

Source: Clark and Schieber (2002). "The Emergence of Hybrid Pensions and Their Implications for Retirement Security in the 21st Century. " in Cash Balance Pension Plan Symposium, Society of Actuaries Spring Meeting in Dallas (May 31). Authors' calculations. 
Figure 4. Median Expected and Actual Retirement Age, Average 1994-2004, Retirement Confidence Survey

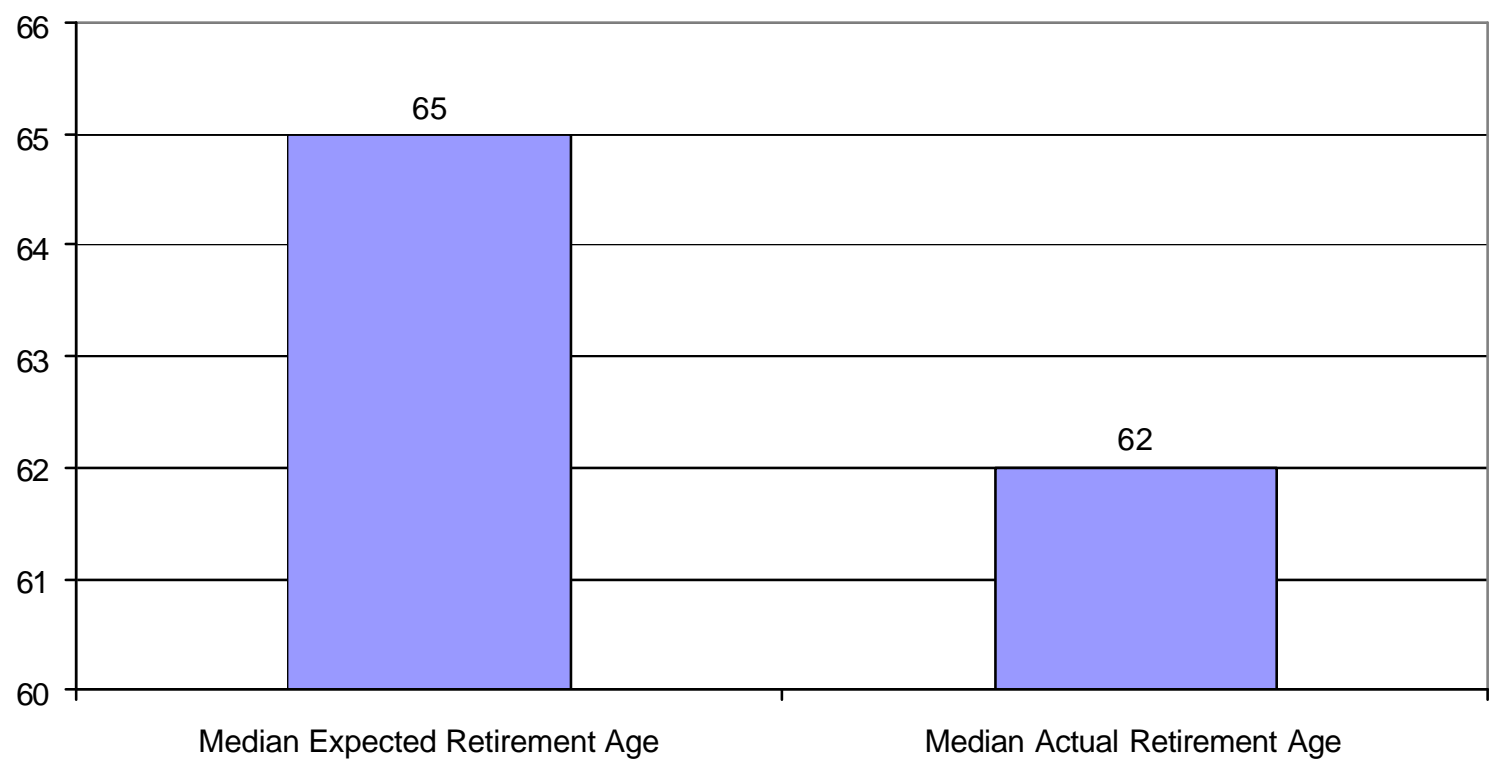

Source: Authors' calculations from the Retirement Confidence Survey (RCS), 1994-2004. 


\section{RECENT WORKING PAPERS FROM THE \\ CENTER FOR RETIREMENT RESEARCH AT BOSTON COLLEGE}

Why Don't Americans Save

Barry Bosworth, November 2004

How Do Pensions Affect Expected and Actual Retirement Ages?

Alicia H. Munnell, Robert K. Triest, and Natalia A. Jivan

Sliding Into Poverty? Cross-National Patterns of Income Source Change and Income Decay in Old Age

James M. Williamson and Timothy M. Smeeding

The Well-Being Of Retirees: Evidence Using Subjective Data

Keith A. Bender, November 2004

The Impact of Aging on Financial Markets and the Economy: A Survey

Barry P. Bosworth, Ralph C. Bryant and Gary Burtless, October 2004

Social Security Personal-Account Participation with Government Matching

Gary V. Engelhardt and Anil Kumar, October 2004

Providing Guarantees in Social Security

Karen E. Smith, C. Eugene Steuerle, and Pablo Montagnes, August 2004

Deferring Income in Employer-Sponsored Retirement Plans: The Dynamics of Participant Contributions

Karen E. Smith, Richard W. Johnson, and Leslie A. Muller, August 2004

Reform Model Two of the President's Commission to Strengthen Social Security: Distributional Outcomes Under Different Economic and Behavioral Assumptions Melissa M. Favreault, Joshua H. Goldwyn, Karen E. Smith, Lawrence H. Thompson, Cori E. Uccello, and Sheila R. Zedlewski, August 2004

An Analysis of How Individuals React to Market Returns in One 401(k) Plan Julie Agnew, April 2004

The Effects of Health Insurance and Self-Insurance on Retirement Behavior Eric French and John Bailey Jones, April 2004

Valuing Assets in Retirement Saving Accounts

James M. Poterba, April 2004

All working papers are available on the Center for Retirement Research website (http://www.bc.edu/crr) and can be requested by e-mail (crr@ bc.edu) or phone (617-552-1762). 